Modernity Unbound: Birmingham, Shakespeare, and the French Revolutions

\title{
Ewan Fernie
}

\section{OpenEdition \\ 1 Journals}

\section{Electronic version}

URL: http://journals.openedition.org/shakespeare/4558

DOI: 10.4000/shakespeare.4558

ISSN: 2271-6424

Publisher

Société Française Shakespeare

\section{Electronic reference}

Ewan Fernie, « Modernity Unbound: Birmingham, Shakespeare, and the French Revolutions », Actes des congrès de la Société française Shakespeare [Online], 37 | 2019, Online since 07 March 2019, connection on 30 April 2019. URL : http://journals.openedition.org/shakespeare/4558; DOI : 10.4000/ shakespeare. 4558

This text was automatically generated on 30 April 2019.

(c) SFS 


\title{
Modernity Unbound: Birmingham, Shakespeare, and the French Revolutions
}

\author{
Ewan Fernie
}

1 He stood, on his plinth, in a relaxed attitude, as if ready to converse with anyone who happened to be passing through. His was a monument to an alternative Englishness; he was a prophet of a political modernity we frankly have yet to attain. His name was George Dawson (1821-1876), and his story represents a lost chapter of the history of English literature, and of Shakespeare criticism in particular-part of an unfortunate eclipse in British and even world history of Birmingham, Britain's second city, now the youngest and one of the most diverse cities in Europe. During the 1870s and early 1880s, Birmingham acquired the reputation for being "the best-governed city in the world"; ${ }^{\text {in }}$ 1887, the journalist and art critic, Alfred St Johnston, was able to write: "the Birmingham of today is perhaps the most artistic town in England." Dawson's most famous successor in Birmingham, Joseph Chamberlain, said Dawson's name ran through the history of Birmingham institutions as through a stick of rock; ${ }^{3}$ Chamberlain also said if Birmingham had any special characteristics, they were George Dawson's. ${ }^{4}$ When Dawson died, all Birmingham mourned. A first statue was erected in the heart of the city, in what now is Chamberlain Square; this was rejected by the people as an insufficient likeness, but its more suitably lively replacement stood, in Birmingham's central civic square, till 1951, still within living memory. It stood under a canopy decorated with medallions of Shakespeare, Carlyle, Bunyan and Cromwell-a pantheon which tilted the establishment Shakespeare towards the edgy, the partisan, and the downright dangerous.

2 Carlyle (whom Dawson knew personally, and with whom he travelled to the older writer's beloved Germany) links Shakespeare and Cromwell to the French Revolution, because Carlyle wrote prominently on all three topics. But Dawson more effectively joined up the dots. In Carlyle, Dawson found a splendid first principle that is fundamentally Shakespearean, and fundamentally revolutionary: that "every man is a great original fact". ${ }^{5}$ He quotes his Scottish spirit-guide as follows: 
The sans-potato is of the self-same stuff as the super-finest Lord Lieutenant. Not an individual sans-potato human scare-crow but had a life given him out of heaven, with eternities depending on it for once and no second time. With immensities in him, over him, and round him; with feelings which a Shakespeare's speech would not utter, with desires as illimitable as the autocrats of all the Russias! ${ }^{6}$ "inmost heart and generic secret" of all he contemplates, "a man justly related to all things and men, a good man". Setting forth the "lordly spectacle" of Shakespeare's infinite sympathy for "all kinds of men and objects", Carlyle recognised him as harbinger of a new epoch, the "priest of a true Catholicism, the "Universal Church" of the future and of all times". ' He had already written his history of the Revolution with astonishingly, unprecedentedly immanent excitement-as if it were actually happening, as if we were actually there. Dawson drew the moral, relating the excitement Revolution to the Universal Church of the future Carlyle had descried in Shakespeare's text:

There are things in Shakespeare that he would have been burned for, if he had not been a player. There is heresy enough to have carried him to endless stakes, political liberty enough to have made him a glorious Jacobin in evil days, and carried him to destruction and doom. If he had appeared as a divine, they would have burned him; as a politician, they would have beheaded him. ${ }^{8}$

Dawson, like Carlyle, might be described as that unfashionable thing: a Victorian sage. But what is a Victorian sage? Carlyle, indisputably, is one-Ruskin is another, Newman a third: all three wrote widely on society and culture, religion and politics; each carried what was, in its seriousness about ultimate ends, an essentially religious attitude beyond the religious frontier. Dawson spoke rather than wrote, from the lecture platform, in the heterodox church on Edward Street that he and others were pleased to nickname the Church of the Doubters-it says something important about the human contact and impact he was seeking. ${ }^{9}$ Of course sages usually come from somewhere more salubrious than Birmingham-except that Newman was in Birmingham too, for most of his life, after he converted to Catholicism. When a pompous Monsignor Talbot invited him to preach to a better class of Christian in the eternal city, Newman declined coldly, observing, "Birmingham people have souls." ${ }^{10}$ Dawson revered Carlyle, but was unlike him, or Ruskin, or Newman, in that he did not drift or move more actively to the right-if Newman eventually leapt into the arms of the Catholic church, Carlyle's posthumous fate was to be read by Goebbels to Hitler in the Secret Bunker.

Dawson, by contrast, was pursued across Europe as a dangerous progressive; he remained proud of his police mug-shots. ${ }^{11}$ He kept faith with what he called "the communism of Christianity", even if it had not yet flourished on the earth. ${ }^{12}$ Carlyle, Ruskin and Newman all linked arms against the modern world. But Dawson embraced the industrial present and looked for the future, in Birmingham. When Ruskin visited the town in 1877, a year after Dawson's death, he found Dawson had left behind him not the uncivilized cultural desert he had expected but a practical group of civic leaders devoted to making an alternative culture quite different from the quixotic old-world pastoralism of Ruskin's own Guild of St George. ${ }^{13}$ Emerson, the American sage with whom Dawson (and Carlyle) were acquainted, was more progressive than Carlyle; Dawson walked the barricades of Paris with him after the revolution of $1848 . .^{14}$ But when they both lectured in Manchester, Emerson's sexless and mandarin style compared unfavourably with Dawson's vigorous extempore engagement with his audiences. ${ }^{15}$ Emerson was thrilled and magnetised but ultimately disappointed by Shakespeare, with whose life he could do nothing progressive. 
${ }^{16}$ But for Dawson, Shakespeare was the conduit for what became known as the Civic Gospel; the channel for bringing into the everyday life of a modern city the passion and mission of religion; "the newest Bible, the sweetest, truest teachings of the truths of the future that the world ever had". ${ }^{17}$ Certainly, no Victorian sage did anything like so much to fashion an actual fairer and more variously and vividly alive social order from the cultural and religious bequest of the past, including Shakespeare, as Dawson did; Karl Marx certainly didn't.

6 The Dawson statue stood right in front of the handsome black railings of the Birmingham Reference Library, which included the Birmingham Shakespeare Memorial Library, which opened at Dawson's behest in 1868. This was the first great Shakespeare collection in the world, and it remains utterly unprecedented in that it belongs to all the people of the city, in accord with what Dawson heralded and welcomed as "an increasing intention to give everything to everybody" characteristic of the modern age. ${ }^{18}$ At least one Birmingham contemporary was sure that Shakespeare himself would favour "being enshrined in the memories and hearts of hard-working men in this town", "clearing and illuminating the path of the hard-working artisan", while "the leaves of his divine works were being turned over by the hardy hands of our own forgemen" over "any sculptured marble, or star-pointing pyramid". ${ }^{19}$ Dawson threw Shakespeare open, believing "that one of the highest offices of civilization is to determine how to give access to the masterpieces of art and of literature to the whole people", insisting it was a "great mistake" to suppose that "art, science, and knowledge" require to be "preached down" to them. ${ }^{20}$ Today, Birmingham's Shakespeare Library boasts holdings in some 93 languages, more than 40,000 volumes, 15,000 playbills, 2000 pieces of music, a vast collection of posters and scrapbooks, and many extraordinary treasures. It is the most tangible remaining legacy of Dawson's Civic Gospel; its First Folio, for which Joseph Chamberlain himself made a substantial contribution, belongs to every Muslim from Sparkbrook, and to every Polish builder. Not that they know it.

7 Confirmation of the centrality of the Shakespeare Library to Dawson's Civic Gospel comes from the great civic architect who was also a prominent member of the Birmingham Our Shakespeare Club of which Dawson was life president, and a subscriber to the Shakespeare Memorial Library: J. H. (no relation to Joseph) Chamberlain. Chamberlain was the architect of Joseph Chamberlain's Highbury House and the handsome Birmingham Board Schools as well as of the Library's handsome (still extant) Shakespeare Memorial Room. He said "[h]e should like the Shakespeare idea to grow in the same proportion as the accumulation of their Shakespeare property", and (even more revealingly) that "the Shakespeare Library ought to be the very best room in town, not excepting the Council Chamber of the new municipal buildings": ${ }^{21}$ these stood on the next side of the square over which the Dawson monument presided. In Birmingham they not only claimed for Shakespeare "a higher morality than had perhaps ever been claimed before"; ${ }^{22}$ they really did believe that this teaching could show the way to modern municipal government, and thus the members of Dawson's Our Shakespeare Club rushed to take up public office: eleven sat on the Town Council, of whom five were Mayor; eight held seats on those Committees which had charge of the literary, artistic and scientific life of the city; five had seats in Parliament; three of those were in the Government. ${ }^{23}$

8 And if Dawson's statue stood appropriately in front of the Shakespeare Library and hard by the Council House, it equally appropriately stood just a few paces from the Town Hall, the first of the great town halls which would come to characterise Victorian England, and 
the scene of many of Dawson's most triumphant and purposive contributions to Birmingham's civic culture, agitating, for instance, for Polish independence; or to impeach the government who had fought the Crimean War; or to purchase Shakespeare's birthplace for the nation. Over the course of two Tuesdays in December, 1849, Dawson taught the city about "Social Reformation, Its Apostles and Systems", from the medieval German Peasants' Revolt of the Middle Ages to the meaning of and rationale for (then) present-day Communism..$^{24}$ He praised the French Revolution for its "visionary" defiance of "the state of man as he is" and "the state of society as it is" (even if he did put some of Robespierre's transports down to indigestion). ${ }^{25} \mathrm{He}$ honoured St. Simon for broaching "the great question of capital and labour", and especially for seeing that "the great blunder of capital was its inheritance". ${ }^{26}$ Dawson also affirmed that "wheresoever prejudice of sectarianism did not put the sexes on an equality, there remained a vestige of social slavery to be abolished". ${ }^{27}$ His voice from the first is remarkable for its sheer unimpeded directness, and its speculative freedom. Even more remarkable is that this young man became, in due course, modern Birmingham's visionary founder, and without ever reining himself in. It was suitable tribute to him that in his memory five hundred homeless people more than once took breakfast in the Town Hall on Christmas Day, even though to the many rough sleepers in Birmingham now, it would seem an impossible fairy-tale.

For Dawson, Revolution was never out of the question, nor beyond comprehension. "Suppose we wish to understand the spirit of the many rebellions, revolutions and overthrows there have been in the earth", he said, perhaps spreading his hands, "let us remember a part of our own history as young men." ${ }^{28}$ If Dawson strode the barricades of Paris in 1848, in Birmingham he recalled with shame the reactionary violence of the Priestly Riots, which had interrupted a dinner to celebrate the Revolution in the city on the $14^{\text {th }}$ of July $1791 .{ }^{29}$ Unto death, Dawson was excited by the prospect of a revolutionary reordering, remarking that the Paris Commune, for all of its wrong-headed excesses, had nevertheless set the agenda for "the great questions which will trouble our children". ${ }^{30} \mathrm{As}$ regards the great French Revolution itself, he despaired "to hear much sentimental twaddle talked". Acknowledging the bloodshed, he nevertheless averred, "legimists should remember, that in this land of ours, in the reign of Henry VIII, more martyrs fell by violent deaths". ${ }^{31}$ To his mind, the case was clear:

The Revolution was caused by the beggary of everything, caused by extravagance and the corruption of the old nobility, and the humiliation of everything to Louis XIV, who said, L'état c'est moi. When a country was in such a state, like a house full of vermin, it was better to apply the torch. ${ }^{32}$

He insisted to his listeners that "the French Revolution has yet to be completed". ${ }^{33} \mathrm{He}$ called for those with "falcon gaze sufficient to pierce through that haze of bloodshed" to see what lay beyond; ${ }^{34}$ and what Dawson himself saw was curiously Shakespearean.

Dawson praised Wordsworth, Cowper and Burns as great "revolutionists" who tore away the "strange artificial dress of metaphor and simile miscalled poetry", and revived a politically potent concreteness and directness he insisted is characteristic of Shakespeare's language..$^{35} \mathrm{He}$ is not unusual of course in drawing attention to Shakespeare's pluralism, but for Dawson this points not so much in the direction of laissez-faire individualism as toward the cultivation of a multifarious selfhood that is at one with liberal solidarity.

His greatness consisted in his harmonious many-mindedness. Most men and women are only parts of men and women, and so conscious are they of it, that they 
have divided themselves into little worlds. There is, for instance, the "religious world," many of whose citizens testify to their shame by carrying the parchment of their citizenship about them-some on their foreheads, others in the whine and twang of their utterance, and others in the supercilious contempt with which they affect to look upon all who are unable to utter their Shibboleth. And then there is a "commercial world," and a "political world." But what is so admirable about this man Shakespeare is that he was everything. ${ }^{36}$ puritans, but now, I must say, it intimates a special lesson for us, as Shakespeare specialists-that there is no such thing as Shakespearean specialism, or rather such specialism is fundamentally misconceived, because what is special about Shakespeare is his inclusive generality.

This is also an irreducibly political point. Voltaire, objected, as Dawson observes, to the grave-diggers in Hamlet, insisting that nothing "so gross and barbarous" would be tolerated "by the vilest populace in France" ${ }^{37}$ Dawson answers Voltaire that, however sophisticated and refined we may suppose ourselves to be, either in Paris or in Birmingham, we have no choice but to tolerate the likes of Shakespeare's gravediggers in our own lives. "When your grave comes to be dug," Dawson asks his listener, "will the diggers weep?"

Do any of you think that the grave-diggers will not joke and jest when they are digging your graves, although the rest of the universe may be in profound sorrow?... Grave-diggers get accustomed to digging graves, and become hardened to it.... If every grave-digger broke his heart over digging a grave, who should we have to dig them?... What did they care for Ophelia? They understood it was a "young woman who had drowned herself." Afterwards they went to dinner. What would become of us if grave-diggers could not eat? Where do you think the under-takers men will be when the parson is saying, "Dust to dust; ashes to ashes" over your corpse? Why, at the "King"s Head," or the "Five Bells," taking their beer. ${ }^{38}$

Such clear-eyed and revolutionary social inclusiveness has, of course, its aesthetic corollary, one which opens up the concept of beauty. For Dawson, Shakespeare's achievement resplendently embodies that divine excess which is the happiest and most hopeful truth of existence: "Shakespeare is a prodigal of beauty; his measure is the great scriptural one-full, pressed down, heaped up, running over-always flexible, and full to profusion." ${ }^{39}$ This profusion necessarily overgoes text-book decorums, and Dawson scorns the small-minded "improvers of Shakespeare" who presume to mop him up.

Voltaire and Tate were alike great in their desire to see villains served out and virtue rewarded. They liked to see a play go off felicitously; and mended God"s ways by offering prizes to good people. So, calling up Cordelia and Hamlet (à la Lady Bountiful in the Sunday School), they presented Cordelia, for being a good girl, with a gold wedding ring and a marriage license on behalf of the Society for securing Poetical Justice, with a hope that, when she was married, she would continue to practise the virtues which had secured her the prize; and presented Hamlet, as a reward of merit, after addressing him on the able manner in which he had discharged his duty and so nobly borne his sorrow, with a first-class certificate and the throne of Denmark. ${ }^{40}$

Elsewhere, he puts it plainly, "Shakespeare rises above morals". ${ }^{41}$ And he growls, "A mutilated Shakespeare, a Shakespeare made moral according to the morality of tattlers and tea-drinkers, we abhor and despise." ${ }^{42}$ Dawson's distinctive, Birmingham-based Bard inducts not just individuals but society as such into a process of enrichment, emancipating the vanguard of history. "There is a prospect," as he puts it, "of the former 
state of divorce being ended": "youth, with its passionate power of enjoyment, and Shakespeare, with his passionate power of development, shall come together-enlarging the knowledge of youth, heightening its intellect, and increasing its power". ${ }^{43}$ Shakespeare above all represents "fulness of power in a people's representative", the power "to throw life into a thousand characters" which cannot be known in advance. That, for Dawson, is perhaps the quintessential power of life as such, and we should promote it in our personal lives, our culture, and our politics. ${ }^{44}$

Highly influenced by the German Romantics, Dawson combines what he calls "selfculture" (Bildung) with French political liberalism. ${ }^{45}$ In more exclusively French terms, he embraces Napoleon AND the Revolution. Dawson praises Bonaparte as "the most intense worshipper of self the world ever knew", a man who "widened the regions of human possibility" and "wrote 'can" upon everything". ${ }^{46}$ But Dawson equally saw this enlargement of humanity in Shakespeare's panoply of characters, and in "the fulness of power" of he who created them. And yet, Shakespeare goes beyond Napoleon's positive capability, and Dawson offers a way of adjusting Keats's famous description of this. The positive capability of a Napoleon (or a Macbeth, or Juliet) becomes negative in Shakespeare only insomuch as it is pluralised, which is to say that it is not so much negated as exceeded. It is exceeded both within the individual character-as richness or ambivalence-and by virtue of the fact that any individual Shakespearean character is but one among many. At the same time, as Dawson recognises, the Shakespearean many remain one, in relation to a given character's identity, and to the shared, encompassing horizon of any individual play, as well as to Shakespeare's whole achievement. What Keats named Shakespeare's "negative capability" is thus, for Dawson, positive capability raised to a higher power ${ }^{47} \mathrm{He}$ helps us to see that Shakespeare's art makes for a moving (in both senses) picture of and even prescription for individual and collective life as a kind of variegated overarching mind-in-process. The formula is squirreled away in the pop song to which Malvolio alludes in Twelfth Night, "Please one, and please all" (3.4.22); ${ }^{48}$ its Biblical equivalent is, as Dawson notes, "the sublime prayer of Moses, "Would to God that all the Lord's people were prophets!" ${ }^{49}$ Its great potential political fruition is a beautiful, open-ended spirit of unity engendered in pure freedom. ${ }^{50}$

For Dawson, Shakespeare is a radical liberal, who takes us beyond the cordon of partypolitical liberalism, involving all others. Today's Left sneer at and define themselves against liberalism, which is regarded as soft or worse-complicit or identical with the form of late-capitalism inimical to communitarian politics we now call "neoliberalism". But what Dawson tried to do in Birmingham at the onset of the modern age suggests we haven't so much grown out of the radical liberal project as we have failed at it. Dawson presents Shakespeare as a blueprint for cultural creativity that could fulfil the promise of the French Revolution. He worked on countless committees in Birmingham so that the people of the city had decent means and conditions of existence: work, rest, clean water, etc. But existence, for Dawson, was never enough. He strove to offer more life to all, accordingly to a vibrant and strenuous Shakespearean vision where people in their maximum diversity struggle to achieve the richest, most contested, and most meaningful communal truth. It gives us, I propose, the measure of our incomplete modernity; it restores to us an alternative, revolutionary Englishness as it was pioneered in Birmingham; and it gives us back an alternative Shakespeare, who is the one I think we most need. 


\section{NOTES}

1. Quoted in Asa Briggs, Victorian Cities, Harmondsworth, Penguin, 1990, p. 184; see also J. Ralph, “The best-governed city in the world," in Harper's Monthly Magazine, New York, June 1890.

2. A. St Johnston, "The Progress of Art in Birmingham," in The Magazine of Art, London, 1887; see Roy Hartnell, "Art and Civic Culture in Birmingham in the Late Nineteenth Century", Urban History 22.2 (1995), p. 229-37, 229

3. George Dawson Collection, vol. 21, Newspaper Cuttings, 1874-5, p. 223-4, Library of Birmingham.

4. George Dawson Collection, 21, p. 2.

5. Quoted in George Dawson, Biographical Lectures, ed. George St Clair, London, Kegan Paul, Trench \& Co., 1887, p. 378.

6. Quoted in Dawson, p. 395.

7. Thomas Carlyle, On Heroes, Hero-Worship and the Heroic in History, ed. and intro. Carl Niemeyer, Lincoln, Nebraska, University of Nebraska Press, p. 104-5, 111.

8. George Dawson, Shakespeare and Other Lectures, ed. George St. Clair, London: Kegan Paul, Trench \& Co., 1888, p. 105.

9. See Wright Wilson, The Life of George Dawson, M.A. Glasgow, Being an account of his Parentage and his Career as a Preacher, Lecturer, Municipal and Social Reformer, Politician and Journalist, Birmingham: Perceval Jones Limited, 1905, p. 60.

10. Quoted in Lytton Strachey, Eminent Victorians, 1918; Oxford, Oxford University Press, 2003, p. 67.

11. See Dawson, Biographical Lectures, p. 140.

12. George Dawson, The Authentic Gospel, ed. George St. Clair, London, Kegan Paul, Trench \& Co., 1881 , pp. $117 \mathrm{ff}$.

13. Tim Hilton, John Ruskin: The Later Years, New Haven and London, Yale University Press, 2000, p. 357-9.

14. See Samuel Timmins' entry on Dawson in the old Dictionary of National Biography: https:// en.wikisource.org/wiki/Dawson,_George_(1821-1876)_(DNB00) [accessed 21 ${ }^{\text {st }}$ December, 2017].

15. See Martin Hewitt, "Ralph Waldo Emerson, George Dawson, and The Control of The Lecture Platform in Mid-Nineteenth Century Manchester", Nineteenth-Century Prose 25, 1998, 1-23.

16. “The world still wants its poet-priest...": Ralph Waldo Emerson, Emerson on Shakespeare from his Essays on Representative Men, London, De la More Press, 1904, p. 37-8.

17. Dawson, Shakespeare and Other Lectures, p. 103.

18. George Dawson Collection, vol. 11, Lectures, 1845-50, p. 36, Library of Birmingham.

19. Memoirs of the Shakespeare Memorial Library 1861-1870, vol. 1, p. 18, Library of Birmingham.

20. See Dawson, Biographical Lectures, p. 160; and the George Dawson Collection, 11, p. 52.

21. See George Dawson Collection, vol. 1, Materials for Life of George Dawson by Wright Wilson, p. 97, Library of Birmingham; this clipping dates from 1875.

22. George Dawson Collection, 1, p. 195: a report from the Our Shakespeare Club meeting held on Wednesday $25^{\text {th }}$ April, 1877.

23. William Harris, The History of Our Shakespeare Club, Birmingham, The "Journal" Printing Offices, 1903, p. 29-30.

24. George Dawson Collection, 11, p. 443.

25. Ibid., p. 444.

26. Ibid., p. 448. 
27. Ibid., p. 450.

28. Dawson, Biographical Lectures, p. 371.

29. Ibid., p. 511.

30. Quoted in George St. Clair, Our Lost Leader: A Discourse Preached in the Church of the Saviour, Birmingham, December $17^{\text {th }}, 1876$, On Occasion of the Death of George Dawson (Birmingham, E. C. Osborne, 1876), p. 138.

31. Dawson, Biographical Lectures, p. 411.

32. Dawson, Shakespeare and Other Lectures, p. 253.

33. Dawson, Biographical Lectures, p. 421.

34. Ibid., p. 412

35. Ibid., pp. 255, 258

36. Dawson, Shakespeare and Other Lectures, pp. 42-3.

37. Ibid., p. 62.

38. Ibid, p. 63; my emphasis.

39. Ibid., p. 60.

40. Ibid., p. 64.

41. Ibid., p. 104.

42. Ibid., 76.

43. Ibid., 101

44. The French writer with whom Dawson has most in common as a Shakespearean is Victor Hugo. See William Shakespeare, trans. M. B. Anderson (1864; A. C. McClurg, Chicago, 1899), pp. 374 373. For Hugo's radical reading of Shakespeare, see Jonathan Bate, "Shakespeare without a muzzle", The Genius of Shakespeare (London, 1997), 230-9 and Peter Holbrook, Shakespeare's Individualism (Cambridge, Cambridge University Press, 2010), p. 13.

45. See, for example, Dawson, Biographical Lectures, p. 251.

46. Ibid., pp. 235, 236.

47. John Keats, The Complete Poetical Works and Letters of John Keats (Boston, Houghton, Mifflin and Company, 1899), p. 277.

48. Shakespeare references are to The Norton Shakespeare, ed. Stephen Greenblatt (London and New York, W. W. Norton, 2008).

49. Quoted in Dawson, Shakespeare and Other Lectures, p. 513.

50. See George Dawson, The Demands of the Age Upon the Church: A Discourse Presented on the Opening of the "Church of the Saviour," Edward Street, Birmingham, on August 8, 1847 (London, C.E Mudie, 1847), p. 11.

\section{ABSTRACTS}

George Dawson (1821-71) was the visionary behind the foundation of the Birmingham Shakespeare Memorial Library for all the people of the city, regardless of class or creed. This article explores the connections he made between Shakespeare and the revolutions in France. In 1848, Dawson strode the barricades of Paris with Emerson. He was also acquainted with Thomas Carlyle. His understanding of Shakespeare's revolutionary potential drew from but also differed from the ideas about the Bard developed by these more famous thinkers. For Dawson, what Keats termed Shakespeare's "negative capability" is positive capability raised to a higher power: the 
capacity to enter into and realise not just one but any number of characters. This inspired and informed the ambitious liberalism of Dawson's "Civic Gospel”, helping to make late-nineteenthcentury Birmingham a progressive modern city, from which we can still learn today.

C'est au visionnaire George Dawson (1821-71) que l'on doit la création de la Birmingham Shakespeare Memorial Library, ouverte à tou.te.s, sans distinction de classe ou de croyance. Le présent article explore les liens qu'il fit entre Shakespeare et les révolutions en France. En 1848, Dawson monta aux côtés d'Emerson sur les barricades parisiennes. Il rencontra aussi Thomas Carlyle. La vision que Dawson avait du potentiel révolutionnaire de Shakespeare s'inspirait, tout en étant différente, des théories que ces penseurs mieux connus avaient développées à propos du Barde. Pour Dawson, ce que Keats nommait la "capacité négative » est en réalité une capacité positive dotée d'une plus grande puissance, celle de faire corps avec et de réaliser non pas un seul mais un nombre infini de personnages. C'est ce qui inspira et nourrit le libéralisme ambitieux de « l'Évangile Civil » de Dawson, qui contribua à faire de Birmingham, à la fin du XIXe siècle, une ville moderne et progressiste, dont nous avons encore à apprendre aujourd'hui.

\section{INDEX}

Mots-clés: Birmingham Shakespeare Memorial Library, capacité négative, Carlyle, Emerson, George Dawson, Keats, 1848

Keywords: Birmingham Shakespeare Memorial Library, Carlyle, Emerson, George Dawson, Keats, negative capability, 1848

\section{AUTHOR}

\section{EWAN FERNIE}

Shakespeare Institute 